\title{
Test Context
}

National Cancer Institute

\section{Source}

National Cancer Institute. Test Context. NCI Thesaurus. Code C49048.

A user environment where a curator may explore curation techniques or illustrate options without making the work products available for general use. 